\title{
The duty to investigate right to life violations across three regional systems: harmonisation or fragmentation of international human rights law?
}

\section{By Philip Leach, Rachel Murray and Clara Sandoval}

Forthcoming in Carla Buckley, Philip Leach and Alice Donald, Harmonisation of International Human Rights Law (Brill, 2015), Published as part of the Nottingham Studies on Human Rights Series (edited by Michael O'Flaherty and David Harris).

\section{Introduction}

All three of the main regional human rights treaties, the European Convention on Human Rights, the American Convention on Human Rights and the African Charter on Human and Peoples' Rights, have been interpreted to include a specific, positive duty to investigate violations of the right to life. This chapter provides a comparative analysis of the jurisprudence on point of the European Court of Human Rights, the Inter-American Commission and Court of Human Rights and the African Commission and Court on Human and Peoples' Rights. It will consider whether there is harmonization or fragmentation of international human rights law in this area; what the consequences are for human rights protection and whether harmonization is desirable in those areas related to the duty to investigate, such as reparations, where strong divergence is found across the regional systems.

The chapter seeks first to analyse the nature of the investigative duty and its various elements, as well as how it arises. It considers to what extent there are differences in investigatory standards as between individual and systemic cases, and as between enforced disappearances and other right to life cases. It assesses the legitimacy of domestic amnesty laws and statutes of limitation and the application by the three regional systems of admissibility criteria and the burden of proof. Finally, it considers the inter-relationship of the right to life and the right to know the truth, before turning to the question of reparations.

\section{The duty to investigate}

The duty to investigate fatal incidents derives in each of the regional treaties not only from the specific substantive provisions on the right to life, but also from the more general obligations to ensure that the rights in the treaties are upheld, namely Article 1(1) of the American Convention 
on Human Rights, ${ }^{1}$ and Article 1 of both the African Charter on Human and Peoples' Rights $(\mathrm{ACHPR})^{2}$ and of the European Convention on Human Rights $(\mathrm{ECHR}) .{ }^{3}$ None of these regional treaties refers expressly to an obligation on the state to conduct an investigation, ${ }^{4}$ but for more than two decades the case-law of the three regional systems has cemented such a duty into the corpus of international human rights law, and has elaborated and refined more clearly what the obligation entails.

\section{A. Concept of due diligence and general principles of the duty to investigate}

A general concept of due diligence in carrying out investigations has been relied on and developed by all three of the regional systems, with varying degrees of specificity and detail. The wording utilized to characterise the overall standard differs: the African Commission has expressly adopted the standard of due diligence from the Inter-American Court's judgment in Velásquez Rodríguez, ${ }^{5}$ whereas the European Court has tended principally to focus on the need for an 'effective, official investigation'. ${ }^{6}$ Nevertheless, there are a number of core constituent elements of the duty to investigate which can be seen from each of the regional systems, but which have perhaps been articulated most explicitly and consistently by the European institutions. ${ }^{7}$ These are as follows:

\footnotetext{
1 Inter-American Court, Velásquez Rodríguez v Honduras, Merits, Judgment of 29 July 1988, Series C No 4 (1988), para 166. Article 4 of the American Convention provides for the right to life.

${ }^{2}$ African Commission, 74/92, Commission Nationale des Droits de l'Homme et des Libertés v Chad (1995), and 245/02, Zimbabwe NGO Human Rights Forum v Zimbabwe (2006), para 153. Article 4 of the African Charter provides for the right to life.

${ }^{3}$ European Court, McCann v UK, Application No 18984/91, Judgment, 27 September 1995, para 161. Article 2 of the European Convention provides for the right to life.

${ }^{4}$ However, other more recently adopted regional treaties contain an express obligation to investigate deaths and/or torture and/or forms of violence. See, for example: Article 8 of the Inter-American Convention to Prevent and Punish Torture (1985); Article 7(b) of the Inter-American Convention on the Prevention, Punishment and Eradication of Violence against Women ('Convention of Belém do Para') (1994); Articles I and III of the Inter-American Convention on the Forced Disappearance of Persons (1994). At the international level, see, for example, Article 3 of the International Convention for the Protection of All Persons from Enforced Disappearance (2006).

${ }^{5}$ African Commission, Zimbabwe Human Rights NGO Forum v Zimbabwe, supra n 2, paras 146-148. ${ }^{6}$ European Court, Hugh Jordan v UK, Application No 24746/94, Judgment, 4 May 2001, para 105. The European Court has referred to the need for the authorities to act with 'exemplary diligence' (see, e.g., European Court, Öneryıldız v Turkey, Application No 48939/99, Judgment, 30 November 2004, para 94). It has referred to the concept of 'due diligence' most often in relation to the duty to protect life under Article 2 (see, e.g., European Court, Opuz v Turkey, Application No 33401/02, Judgment, 9 June 2009, paras 131 and 137-149). See also European Court, Banel v Lithuania, Application No 14326/11, Judgment, 18 June 2013, paras 71-72.

${ }^{7}$ See, by way of example, European Court, Hugh Jordan v UK, ibid, paras 105-109.
} 
(i) Instigate investigation on own initiative

All three systems require that the State instigate the investigation on its own initiative: it cannot be left to the victims, complainants or next-of-kin to lodge a complaint and the State cannot avoid its obligations by arguing that it did not investigate because the victim failed to lodge a complaint. $^{8}$

\section{(ii) The investigation should be effective}

For all three systems a simple requirement to investigate is not enough, ${ }^{9}$ the investigation must be effective. ${ }^{10}$ In order to satisfy this requirement, it cannot be determined in the abstract: ${ }^{11}$ 'each case must be treated on its own merits depending on the specific circumstances of the case and the rights violated'. ${ }^{12}$ The European Court, therefore, has held that the authorities must take reasonable steps to secure the evidence concerning the incident, including, inter alia, eyewitness testimony, forensic evidence and, where appropriate, an autopsy providing a complete and accurate record of injury and an objective analysis of clinical findings, including the cause of death. ${ }^{13}$ The European Court has also stipulated that any deficiency in the investigation which undermines its ability to identify the perpetrator or perpetrators will risk falling foul of this standard. ${ }^{14}$ The obligation to investigate effectively may of course have implications for the provision of the necessary resources, which has been expressly noted by the African Commission. ${ }^{15}$

The Inter-American Court has underlined that the effectiveness of an investigation into a killing has to be visible from

\footnotetext{
${ }^{8}$ Inter-American Court, Velásquez Rodríguez v Honduras, supra n 1, para 177; Manuel Cepeda Vargas v Colombia, Preliminary objections, merits, reparations and costs, Judgment of 26 May 2010, Series C No 213 (2010), para 117; African Commission, 275/03, Article $19 v$ State of Eritrea (2007), para 72; European Court, Ilhan v Turkey, Application No 22277/93, 27June 2000, para 63.

${ }_{9}^{9}$ African Commission, 279/03-296/05, Sudan Human Rights Organisation and Centre on Housing Rights and Evictions (COHRE) $v$ The Sudan (2009), para 149.

10 See, for example, African Commission, Resolution on Guidelines and Measures for the Prohibition and Prevention of Torture, Cruel, Inhuman and Degrading Treatment or Punishment in Africa (Robben Island Guidelines), ACHPR/RES/61, 2002, article 19.

11 Inter-American Court, Velasquez Rodriguez v Honduras, supra $n 1$.

12 African Commission, Zimbabwe Human Rights NGO Forum v Zimbabwe, supra n 2, para 155.

${ }^{13}$ European Court, Anguelova v Bulgaria, Application No 38361/97, Judgment, 13 June 2002, para 139.

${ }^{14}$ European Court, Ramsahai and others v Netherlands, Application No 52391/99, Judgment, 15 May 2007, para 324.

${ }^{15}$ African Commission, 48/90-50/91-52/91-89/93, Amnesty International, Comité Loosli Bachelard and Lawyers Committee for Human Rights, Association of Members of the Episcopal Conference of East Africa $v$ Sudan, (1999).
} 
'...the first proceedings with all diligence....State authorities that carry out an investigation must, inter alia, a) identify the victim; b) recover and preserve the evidentiary material related to the case; $c$ ) identify possible witnesses and obtain their statements with regard to the death that is being investigated; d) determine the cause, form, place, and moment of death, as well as any proceeding or practice that could have caused it, and e) distinguish between a natural death, an accidental death, a suicide, or a homicide. Besides, it is necessary to thoroughly investigate the crime scene, autopsies and competent professionals employing the most appropriate procedures must carefully practice analysis of the human remains. ${ }^{16}$

A further requirement, identified by the Inter-American Court in Velásquez Rodríguez and cited expressly by the African Commission, is that the investigation should be 'serious'. However, this does not appear to have a different meaning to the need to conduct a diligent investigation. According to the Inter-American Court, the State has a legal duty "to use the means at its disposal to carry out a serious investigation of violations committed within its jurisdiction, to identify those responsible, to impose the appropriate punishment and to ensure the victim adequate compensation". ${ }^{17}$ Equally, the Court has maintained that "an investigation must have an objective and be assumed by the State as its own legal duty, not as a step taken by private interests that depends upon the initiative of the victim or his family or upon their offer of proof, without an effective search for the truth by the government". To this, the African Commission has added that the seriousness of the investigation must be evaluated 'through the actions of both State agencies and private actors on a case-by-case basis'. ${ }^{18}$ The Commission has therefore required that States 'use the means at its disposal to carry out a serious investigation of violations committed within its jurisdiction, to identify those responsible, to impose the appropriate punishment and to ensure the victim adequate compensation'. ${ }^{19}$

Furthermore, where new evidence subsequently comes to light, an effective investigation requires that State authorities are 'sensitive to any information or material which has the potential either to undermine the conclusions of an earlier investigation or to allow an earlier inconclusive investigation to be pursued further'. ${ }^{20}$ In making such assessments, the authorities are entitled to take account of the passage of time and the prospects of success:

'the fresh obligation to investigate will vary according to the nature of the purported new evidence or information. It may be restricted to verifying the reliability of the new evidence and the authorities can legitimately take into account the prospects of launching a new prosecution at such a late stage. Due to the lapse of time, the level of urgency may have diminished; the immediacy of required investigative steps in the aftermath of an incident is likely to be absent'. ${ }^{21}$

Whilst recognizing the challenges of access to witnesses in such circumstances, which may impair the availability of sufficient evidence for a prosecution, the European Court has held that the authorities 'must take reasonable steps to find the available evidence and pursue the practicable leads open to them at this

16 Inter-American Court, Miguel Castro Castro Prison v Peru, Merits, reparations and costs, Judgment of 25 November 2006, Series C 160 (2006), para 383.

17 Inter-American Court, Velásquez Rodríguez v Honduras, supra n 1, para 179.

${ }^{18}$ African Commission, Zimbabwe Human Rights NGO Forum v Zimbabwe, supra n 2, para 158.

19 lbid.

20 European Court, Brecknell v UK, Application No 32457/04, Judgment, 27 November 2007, para 70.

${ }^{21}$ European Court, Charalambous and others v Turkey, Application No 46744/07, Decision, 3 April 2012. 
time to discover the perpetrators of any unlawful violence', and that 'the families should be kept informed of any key factual conclusions and procedural developments and any reasoned decisions in this regard'. ${ }^{22}$

How far does the effectiveness obligation extend?

For the European Court, whilst the requirements of Article 2 do not, as such, guarantee a right to have criminal proceedings instituted against third parties, ${ }^{23}$ they do extend beyond the stage of the official investigation, where this has led to the institution of proceedings in the national courts. In that situation, the proceedings as a whole, including the trial stage, must satisfy the requirements of the positive obligation to protect lives through the law. Thus, instigating criminal proceedings, which are then pursued effectively, will usually be sufficient to meet the Article 2 requirement to investigate a fatality. ${ }^{24}$ The Strasbourg Court has emphasized that 'in the normal course of events a criminal trial, with an adversarial procedure before an independent and impartial judge must be regarded as furnishing the strongest safeguards of an effective procedure for the finding of facts and the attribution of criminal responsibility'. ${ }^{25}$ However, criminal proceedings which fail to address a 'crucial issue' (even where some suspects are tried, convicted and sentenced), ${ }^{26}$ or which fail to include a particular individual/company, ${ }^{27}$ or which are not sufficiently prompt ${ }^{28}$ may violate Article 2 . Furthermore, inadequate reasoning of domestic courts in acquitting state officials may breach Article $2,{ }^{29}$ as may the imposition of only relatively light sentences ${ }^{30}$ or the failure to ensure that those convicted serve their sentences. ${ }^{31}$

Although the African Commission has not elaborated as to precisely how far it considers the right to life extends, the Inter-American Court, like the European Court, requires that the prosecution and punishment of perpetrators should be effective. Incidents of torture, killing and enforced disappearance 'entail the activation of national and international measures, instruments and mechanisms to ensure their effective prosecution and the sanction of the

\footnotetext{
$22 \mathrm{lbid}$, para 65.

${ }^{23}$ European Court, Perez v. France, Application No 47287/99, Judgment, 12 February 2004, para 70.

24 European Court, Brecknell v UK, Application No 32457/04, Judgment, 27 November 2007, para 66.

${ }_{25}$ European Court, McKerr v. UK, Application No 28883/95, Judgment, 4 May 2001, para 134.

${ }^{26}$ European Court, Avşar v Turkey, Application, No 25657/94, Judgment, 10 July 2001.

27 European Court, Kalender v Turkey, Application No 4314/02, Judgment, 15 December 2009.

${ }^{28}$ European Court, Opuz v Turkey, Application No 33401/02, Judgment, 9 June 2009.

29 European Court, Gülv Turkey, Application No 22676/93, Judgment, 14 December 2000.

${ }^{30}$ European Court, Şimşek and others v Turkey, Applications Nos 35072/97 and 37194/97, Judgment, 26 July 2005.

${ }_{31}$ European Court, Agache and others v Romania, No 2712/02, Judgment, 20 October 2009.
} 
authors, so as to prevent them and avoid them remaining unpunished' ${ }^{32}$ Indeed, in the case of Mapiripán v. Colombia, while an investigation was opened, the criminal proceedings were considered ineffective as "the majority of those responsible ha[d] not been formally joined to the investigations, or they ha[d] not been identified or prosecuted [...] and the trial and conviction in absentia of the paramilitary who, [...] ha[ve] benefited from the way the judicial system has acted, convicting them but without executing the punishment." ${ }^{\prime 33}$

Is it an obligation of means or result?

Both the Inter-American and European bodies have held that the duty to investigate represents an obligation of means, not of result. Thus the European Court, for example, accepts that not every investigation will necessarily be successful. ${ }^{34}$ At the same time, the Inter-American Court has underlined that the obligation cannot be fulfilled as "a simple formality predestined to be unsuccessful' ${ }^{35}$ but that it must be 'directed at a specific goal, the determination of the truth and the investigation, pursuit, capture, prosecution and, as appropriate, punishment of those responsible for the facts'. ${ }^{36}$ The European Court has insisted that the investigation must be 'capable of leading to a determination of whether the force used was or was not justified in the circumstances and to the identification and punishment of those responsible'. ${ }^{37}$

The African Commission appears to take a different position, although this has not been expressed in the particular context of the duty to investigate, but rather in relation to the general obligation to give effect to the Charter rights (under Article 1). The Commission has held that Article 1:

'imposes on the States Parties the obligation of using the necessary diligence to implement the provisions prescribed by the Charter since the said diligence has to evolve in relation to

32 Inter-American Court, Goiburú et al. v Paraguay, Merits, reparations and costs, Judgment of 22 September 2006, Series C 153 (2006), para 128.

33 Inter-American Court, Mapiripán Massacre v Colombia, Merits, reparations and costs, Judgment of 15 September 2005, Series C 134 (2005), para 240.

${ }^{34}$ European Court, Aslakhanova and others v Russia, Application Nos 2944/06, 8300/07, 50184/07, 332/08, 42509/10, Judgment, 18 December 2012, para 144 (as regards investigations into allegations of ill-treatment).

35 Inter-American Court, Velásquez Rodríguez v Honduras, supra n 1, , para 177.

36 Inter-American Court, Cantoral Huamaní and Garcia Santa Cruz v Peru, Preliminary objection, merits, reparations and costs, 10 July 2007, Series C 167 (2007), para 131. Inter-American Court, Pueblo Bello Massacre $v$ Colombia, 31 January 2006, Series C 140 (2006), para 143.

${ }^{37}$ European Court, Al-Skeini v UK, Application No 55721/07, Judgment, 7 July 2011, para 166. 
the time, space and circumstances, and has to be followed by practical action on the ground in order to produce concrete results. ... In fact, in the Commission's view, it is an obligation of RESULT that Article 1 of the African Charter imposes on the States Parties. In effect, each State has the obligation of guaranteeing the protection of the human rights written in the Charter by adopting not only the means that the Charter itself prescribes, in particular 'all the necessary legislative measures for this purpose but in addition measures of their choice that the Charter called for by Article 1 and it therefore defined as one of result'. ${ }^{38}$

It clarifies this by drawing upon Articles 20 and 21 of the International Law Commission's Draft articles on State responsibility, Colozza $v$ Italy, De Cubber v Belgium before the European Court and Avena before the ICJ, noting that: 'the distinction between the obligation of diligence and that of result should not make one lose sight of the fact that, all obligations contained in a Treaty, Convention or a Charter seek to attain an objective, a purpose or a result'. ${ }^{39}$

Furthermore, in the same case the Commission found that:

'The obligations prescribed by the African Charter in its Article 1 impose on the States Parties (the State of Cameroon included) the need to put in place all measures liable to produce the result of preventing all violations of the African Charter over their entire territory. ${ }^{40}$

(iii) Promptness and reasonable expedition

For all three systems, the investigation must be prompt and carried out 'without delay'. ${ }^{41}$ For the European Court while there may be obstacles or difficulties which prevent progress in an investigation in a particular situation, a prompt response is essential in maintaining public confidence in the authorities' adherence to the rule of law and in preventing any appearance of collusion in, or tolerance of, unlawful acts. ${ }^{42}$ The requirement for promptness may be stricter in certain cases, such as, for the European Court, investigations into deaths in state custody. ${ }^{43}$

38 African Commission, 272/03, Association of Victims of Post Electoral Violence \& INTERIGHTS v Cameroon (2009), paras 110 - 111.

$39 \mathrm{lbid}$, para 107.

$40 \mathrm{lbid}$, para 119-121.

41 Inter-American Court, Contreras et al. v El Salvador, Merits, reparations and costs, Judgment of 25 October 2012, Series C No 232, para 128. African Commission, Sudan Human Rights Organisation and Centre on Housing Rights and Evictions (COHRE) $v$ The Sudan, supra n 9, para 150. See also Robben Island Guidelines, supra n 10.

42 European Court, Yaşa v Turkey, Application No 22495/93, Judgment, 2 September 1998, paras 102-4.

43 Eurpean Court, Trubnikov v Russia, Application No 49790/99, Judgment, 5 July 2005, para 88. 
In the Inter-American System, the obligation to investigate is also linked to important obligations deriving from Articles 8 and 25 of the American Convention which regulate due process guarantees and the right to judicial and other remedies. Under Article 8 in conjunction with Article 1(1), States have an obligation to carry out an investigation within a reasonable period of time. This means both that the investigation into a fatality needs to be opened as soon as the State has notice of it and that it should be carried out within a reasonable period of time. Indeed, the Inter-American Court considers that 'the right to a fair trial requires that the determination of the facts under investigation and, if it were the case, of the corresponding criminal responsibilities be made effective in a reasonable period of time, reason for which, in attention to the need to guarantee the rights of the affected parties, a prolonged delay can constitute, in itself, a violation of the right to a fair trial'. ${ }^{44}$

\section{(iv) Independence and impartiality}

All three systems underscore the importance of those undertaking the investigations to be impartial and independent from those implicated in the events. ${ }^{45}$ The European Court and African Commission have clarified this further by noting elements of hierarchical, institutional and practical independence. ${ }^{46}$ Judicial impartiality, for example, will be undermined 'when ... a judicial official secretly participated in the investigation of a case'. ${ }^{47}$

\section{(v) Involvement of next of kin and victims}

In all three regional systems it has been held that the victims or their next of kin have a right to be involved in the procedure if they so wish and to the extent necessary to safeguard their legitimate interests. ${ }^{48}$ For the Inter-American system this principle also derives from the

\footnotetext{
44 Inter-American Court, Radilla Pacheco v Mexico, Preliminary objections, merits, reparations and costs, Judgment of 23 November 2009, Series C 209 (2009), para 191.

${ }^{45}$ African Commission, Amnesty International, Comité Loosli Bachelard and Lawyers Committee for Human Rights, Association of Members of the Episcopal Conference of East Africa v Sudan, supra n 15.

46 European Court, Og̃ur v Turkey, Application No 21954/93, Judgment, 20 May 1999, paras 91-2. The African Commission uses the same wording in Sudan Human Rights Organisation \& Centre on Housing Rights and Evictions (COHRE) v The Sudan, supra n 9, para 150.

${ }^{47}$ African Commission, Principles and Guidelines on the Right to a Fair Trial and Legal Assistance in Africa, 2003, para 5(d).

${ }^{48}$ European Court, Anguelova v Bulgaria, supra n 13, para 140.
} 
importance attributed to the right to know the truth. ${ }^{49}$ In addition, according to the Inter-American Court 'the state must ensure that the next of kin of the victims have full access and capacity to act at all stages and in all instances of the proceedings in accordance with the American Convention [...] The purpose of this participation must be access to justice, knowledge of the truth about what happened, and obtaining fair reparation. ${ }^{50}$ Similarly, albeit not in the context of a finding on an individual communication, the African Commission has also noted that investigations need to be 'readily accessible', namely that there are 'fully independent mechanisms to which all persons can bring their allegations [of torture and ill-treatment]'. ${ }^{51}$

The European Court has found that victims' families have not been able to participate sufficiently in investigations, where, for example, there was no legal aid and there were restrictions on the extent of the disclosure of case documents in an inquest, ${ }^{52}$ or where the authorities failed to advise a family about the date of an inquest. ${ }^{53}$

\section{B. Triggering moment}

At what point will the obligation to investigate come into existence? For the European Court, the principle is that the duty to investigate will arise 'where lives have been lost in circumstances potentially engaging the responsibility of the State'. ${ }^{44}$ There are particular situations which will clearly trigger the obligation. For example, this will be the case when individuals have been killed as a result of the use of force ${ }^{55}$ in cases of 'disappearances' in circumstances which may be regarded as life-threatening, ${ }^{56}$ and for deaths in custody. ${ }^{57}$ The duty arises, of course, whether or not state agents are implicated. Therefore, 'the mere fact the authorities were informed' of a murder will give rise to an obligation to investigate the circumstances surrounding

\footnotetext{
${ }^{49}$ See section 5 of this article.

50 Inter-American Court, Valle Jaramillo et al. v Colombia, Merits, reparations and costs, Judgment of 7 July 2009, Series C 192 (2008), para 233.

${ }^{51}$ Robben Island Guidelines, supra $\mathrm{n} 10$, article 17.

52 European Court, Hugh Jordan v UK, supra n 6, paras 132-140.

${ }^{53}$ European Court, Rantsev v Cyprus and Russia, Application No 25965/04, Judgment, 7 January 2010 , para 239.

54 European Court, Trubnikov v Russia, Application No 49790/99, Judgment, 5 July 2005, para 85.

55 European Court, Nachova and others v Bulgaria, Applications Nos 43577/98 and 43579/98, Judgment, 6 July 2005, para 110.

${ }^{56}$ European Court, Er and others v Turkey, Application No 23016/04, Judgment, 31 July 2012, para 82.

${ }^{57}$ European Court, Paul and Audrey Edwards v UK, Application No 46477/99, Judgment, 14 March 2002, para 74.
} 
the death. ${ }^{58}$ This is justified on the basis, in the case of homicide, 'not only because any allegations of such an offence normally give rise to criminal liability, but also because often, in practice, the true circumstances of the death are, or may be, largely confined within the knowledge of State officials or authorities'. ${ }^{59}$

The Inter-American Court has not expressly indicated the triggering moment as regards the obligation to investigate violations of the right to life, although it has done so for torture cases. ${ }^{60}$ This is because it has been a common feature of right to life cases that an investigation is formally opened, but that there is then undue delay or the authorities fail to meet the due diligence requirements. In Cotton Field v Mexico, for example, concerning the disappearance and killing of a woman and two girls, after the next of kin of the victims informed the authorities that their relatives were missing, an investigation was opened, but it proved to be only a formality: 'during the first 72 hours, the authorities merely registered the disappearances and the statements of those who reported them [...].' Therefore, 'apart from the formal routine procedures, the State did not submit any arguments or evidence about measures taken in the said period to mobilize its investigative mechanisms in a real and effective search for the victims. ${ }^{61}$ The African System has not provided express comment on this point, however, from the case law of the three regional systems it is possible to conclude that once State authorities know of a possible violation of the right to life they should open an investigation.

\section{Differences in investigatory standards relating to systemic and isolated violations}

In cases where gross and systematic human rights violations are at stake, the Inter-American Court has indicated that the standard of due diligence is higher than that applied in isolated cases. Thus, the Inter-American Court requires the State to 'determine by means of legal proceedings the patterns of joint actions' including all those involved and their levels of

\footnotetext{
58 European Court, Tanrikulu v Turkey, Application No 23763/94, Judgment, 8 July 1999, para 103.

59 European Court, Trubnikov v Russia, Application No 49790/99, Judgment, 5 July 2005, para 87.

60 Inter-American Court, Leopoldo Garcia Lucero and others $v$ Chile, Preliminary objection, merits and reparations, Judgment of 28 August 2013, Series C 267 (2013), paras 124-127.

61 Inter-American Court, González et al (Cotton Field) v Mexico, Preliminary objections, merits, reparations and costs, Judgment of 16 November 2009, Series C 205 (2009), para 180.
} 
responsibility, ${ }^{62}$ and to ensure that the authorities 'assess the systematic patterns that allowed grave human rights violations' to happen. Such investigations should take 'into account the complexity of this type of facts and of the structure in which the facts took place, thus avoiding omissions in the collection of evidence and in following up on logical lines of investigation'. ${ }^{63}$ The European Court does not, as such, impose a higher standard of investigations in systemic cases, but the failure of the investigating authorities to make links between factually similar cases, and to co-ordinate their efforts, will be a relevant factor in deciding whether the obligation to carry out an effective investigation has been breached. ${ }^{64}$

The African Commission has not clarified if the standard is different in such instances although, as will be seen below, it does not require the complainant to exhaust domestic remedies if there is prima facie evidence of 'serious or massive violations'.

\section{Differences in investigatory standards relating to right to life and disappearance cases}

The Inter-American Court has maintained that the nature of an enforced disappearance must shape the way the duty of due diligence is fulfilled by state authorities. So, it is not that the standard is applied differently, as such, but it is that the very nature of an enforced disappearance necessarily impacts upon the way the obligation to investigate is met by state authorities. The Court has stipulated that the state apparatus should take prompt and immediate action to ascertain the whereabouts of the victim as soon as it has been notified that a person has disappeared. ${ }^{65}$

Disappearance cases are frequently characterized by the considerable passage of time since the person was last seen. This may make it difficult to locate eye-witness evidence or to identify and mount a case against the alleged perpetrators. However, the European Court has

\footnotetext{
62 Inter-American Court, Río Negro Massacres v Guatemala, Preliminary objection, merits, reparations and costs, Judgment of 4 September 2012, Series C 250 (2012), para 194.

63 Ibid.

64 European Court, Ülkü Ekinci v Turkey, Application No 27602/95, Judgment, 16 July 2002, para 145; Magomadov and Magomadov v Russia, Application No 68004/01, Judgment, 12 July 2007, para 108; Makhauri v Russia, No Application 58701/00, Judgment, 4 October 2007, para 109 (the failure 'to establish a comprehensive picture of events').

65 Inter-American Court, Contreras et al v El Salvador, Merits, reparations and costs, Judgment of 31 August 2011, Series C 232 (2011), para 145.
} 
emphasized that, even in such a situation, the ambit of the procedural obligation is unambiguous. ${ }^{66}$ The European Court also recognises that there is a consensus in international law that it should be possible to prosecute the perpetrators of crimes such as disappearances even many years after the events. ${ }^{67}$

The Inter-American Court has laid down that acting in a timely manner includes having unrestricted access to places of detention and their documentation, the ability to cross-examine witnesses, as well as the judiciary and/or the prosecutor's office taking all the necessary measures to establish the whereabouts of the person. ${ }^{68}$ The Inter-American Court has also held that for the authorities to be able to carry out their work adequately, they must be provided with 'the logistical and scientific resources necessary for the gathering and processing of the evidence and, specifically, of the powers to access the appropriate documents and information for the investigation of the facts denounced and obtain indicia or evidence of the location of the victims. ${ }^{\prime 69}$ Although the African Commission has drawn upon Inter-American Court jurisprudence in the context of disappearances, it has been less explicit in identifying whether the obligation to investigate is different in such contexts. ${ }^{70}$

For the European Court, the procedural obligation to investigate will arise where there is an arguable claim that an individual, who was last seen in the custody of agents of the State, subsequently disappeared in a context which may be considered life-threatening. ${ }^{71}$ Unlike an investigation into a killing, an investigation into a disappearance does not serve the sole purpose of establishing the circumstances and finding and punishing the perpetrator. The crucial difference in investigations into disappearances is that, by conducting an investigation, the authorities also aim to find the missing person or find out what happened to him or her. ${ }^{72}$ Therefore, the obligation to investigate in the case of a disappearance will persist as long as the

${ }^{66}$ European Court, Varnava and Others v Turkey, Application No 16064/90, 18 September 2009, Judgment, para 191.

${ }^{67}$ European Court, Er and Others v. Turkey, supra n 56, para 57; European Court, Aslakhanova v Russia, supra $n$ 34, para 214.

68 Inter-American Court, Anzualdo Castro v Peru, Preliminary exceptions, merits, reparations and costs, Judgment of 22 September 2009, Series C 202 (2009), para 135; Radilla Pacheco v Mexico, supra n 44, para 215.

69 Ibid, Radilla Pacheco v Mexico, para 222.

70 African Commission, 361/08, J.E Zitha \& P.J.L.Zitha (represented by Prof. Dr. Liesbeth Zegveld) $v$ Mozambique, 1 April 2011, para 80, drawing upon Moiwana Village v Suriname, Ovelario Tames v Brazil, and Blake $v$ Guatemala.

${ }^{71}$ European Court, Cyprus v Turkey, Application No 25781/94, Judgment, 10 May 2001, para 132.

${ }^{72}$ European Court, Er and others v Turkey, supra n 56, para 56 
fate of the person is unaccounted for. The ongoing failure to provide the requisite investigation will be regarded as a continuing violation for all three of the regional systems. ${ }^{73}$

E. Differences in investigatory standards where there is evidence of discrimination

Where other, potentially important factors are evident, such as discriminatory attitudes, the standards applicable to the obligation to carry out an effective investigation may also differ. For example, stricter obligations will arise in investigating racist violence under the European Convention, ${ }^{74}$ or discrimination that involves violence against women under the American Convention and the Inter-American Convention on the Prevention, Punishment and Eradication of Violence Against Women. ${ }^{75}$ The African Commission has not yet been called upon to consider these issues.

\section{Barriers to carrying out effective investigations}

Impunity, de jure or de facto, has been a barrier to ensure that states in Europe ${ }^{76}$ Africa and the Americas carry out their duty to investigate human rights violations. Impunity has been particularly pervasive in the latter two regions due to the presence of armed conflicts or dictatorships, the absence of the rule of law, corruption, the over-riding need to achieve peace and reconciliation and configurations of power that make it extremely difficult to investigate large scale human rights violations. In the three regions, States have invoked amnesty laws, statutes of limitation, the principle of ne bis in idem and other similar legal institutions, the effects of which have been to prevent or hinder investigations.

Therefore all three regional systems have consistently maintained that amnesty laws and statutes of limitation are incompatible with the respective treaties. For example, this is illustrated most clearly by the Barrios Altos v. Peru judgment of the Inter-American Court in 2001:

‘...all amnesty provisions, provisions on prescription and the establishment of measures designed to eliminate responsibility are inadmissible, because they are intended to prevent

\footnotetext{
73 European Court, Varnava and Others, supra n 66, para 148; European Court, Aslakhanova v Russia, supra n 34, para 214; African Commission, J.E Zitha \& P.J.L.Zitha (represented by Prof. Dr. Liesbeth Zegveld) v Mozambique, supra n 70, para 80; Inter-American Court, Anzualdo v Peru, supra n 68, para 59. 74 European Court, Nachova and others v Bulgaria, Applications Nos 43577/98 and 43579/98, Judgment, 26 February 2004, para 157 (endorsed by the Grand Chamber in its judgment of 6 July 2005, para 160). See also European Court, Menson and others v UK, Application No 47916/99, Decision, 6 May 2003; European Court, Angelova and Iliev v Bulgaria, Application No 55523/00, Judgment, 26 July 2007; European Court, Antayev and others v Russia, Application No 37966/07, Judgment, 3 July 2014, para 110. As to the application of these principles vis-à-vis Article 3, see European Court, Bekos and Koutropoulos v Greece, Application No 15250/02, Judgment, 13 December 2005.

75 Inter-American Court, Cotton Field v Mexico, supra n 61, para 293.

${ }^{76}$ European Court, Abdülsamet Yaman v Turkey, Application No 32446/96, Judgment, 2 November 2004, para 55; European Court, Okkalı v Turkey, Application No 52067/99, Judgment, 17 October 2006, para 76.
} 
the investigation and punishment of those responsible for serious human rights violations such as torture, extrajudicial, summary or arbitrary execution and forced disappearance, all of them prohibited because they violate non-derogable rights recognized by international human rights law'77

The African Commission (and the European Court holding similarly ${ }^{78}$ ) has taken note of 'consistent international jurisprudence suggesting that the prohibition of amnesties leading to impunity for serious human rights has become a rule of customary international law, ${ }^{79}$ referring to the Principles on Impunity, the jurisprudence and general comments of the Human Rights Committee, its own jurisprudence and that of the ICTY.

\section{Admissibility and burden of proof}

\section{A. Jurisdiction ratione temporis}

Many gross human rights violations that have been perpetrated in the Americas region took place before the State in question had ratified the American Convention (Argentina ${ }^{80}$ or Chile, ${ }^{81}$ for example) or, at a time when the State had ratified the Convention but had not accepted the jurisdiction of the Inter-American Court (as in the case of Guatemala ${ }^{82}$ ). The Court has acknowledged that it cannot exercise jurisdiction over matters that took place before the state in question ratified the Convention and accepted the jurisdiction of the Court, however, it does exercise jurisdiction over incidents which originally took place before the date of ratification, but whose effects continued after that date, as, for example, in the case of enforced disappearances. ${ }^{83}$ The African Commission has held similarly, distinguishing between

\footnotetext{
77 Inter-American Court, Barrios Altos v Peru, Merits, Judgment of 14 March 2001, Series C 75, para 41.

${ }^{78}$ European Court, Marguš v Croatia, Application No 4455/10, Judgment, 27 May 2014, paras 129-141.

${ }^{79}$ African Commission, Zimbabwe Human Rights NGO Forum v. Zimbabwe, supra n 2, para 201.

${ }^{80}$ Argentina ratified the American Convention and recognised the jurisdiction of the Court on 14 August 1984.

${ }^{81}$ Chile ratified the Convention and accepted the jurisdiction of the Court on 10 August 1990.

82 Guatemala ratified the American Convention on 27 April 1978 and accepted the jurisdiction of the Court on 9 March 1987.

${ }^{83}$ See, for example, Inter-American Court, Blake $v$ Guatemala, Preliminary exceptions, Judgment of 2 July 1996, Series C 27, para 39; Inter-American Court, Serrano Cruz Sisters v El Salvador, Preliminary objections, Judgment of 23 November 2004, Series C 118 (2004), paras 65 and 66; Inter-American Court, Heliodoro Portugal $v$ Panama, Preliminary objections, merits, reparations and costs, Judgment of 12 August 2008, Series C 186 (2008), para 25, and Inter-American Court, Río Negro Massacres v Guatemala, supra n 62, para 37. In Serrano Cruz Sisters, the Inter-American Court made reference to Article 28 of the Vienna Convention on the Law of Treaties 1969 which states as follows: 'Unless a different intention appears from the treaty or is otherwise established, its provisions do not bind a party in relation to any act or fact which took place or any situation which ceased to exist before the date of the entry into force of the treaty with
} 
continuing violations and an 'instantaneous act', holding disappearances to be the former as a 'violation that occurs and continues over time, until it ceases, that is, until the missing person is no longer disappeared'. ${ }^{84}$ In the case of the Beneficiaries of the Late Norbert Zongo and others v. Burkina Faso, ${ }^{85}$ the African Court drew a distinction between the fact of an assassination, in 1998, of a journalist and several of his companions (an instantaneous act), and the subsequent failure to investigate the case. The duty to investigate continued after the date when Burkina Faso accepted the jurisdiction of the Court (January 2004) and accordingly the Court had jurisdiction ratione temporis to consider it.

The Inter-American Court too has maintained that it can exercise jurisdiction over separate and independent violations related to the failure of the state to conduct an impartial and effective investigation. ${ }^{86}$

The European Court has also found that the procedural obligation to investigate fatalities is a separate and autonomous duty - and, therefore, one that is, in the words of the Strasbourg Court, 'detachable' and capable of binding the State even when the death took place before the critical date. In reaching this finding in Šilih v Slovenia, ${ }^{87}$ in 2009, the Grand Chamber reviewed the application of the ratione temporis principle in international law, including the relevant case law of the United Nations Human Rights Committee ${ }^{88}$ and particularly that of the Inter-American Court of Human Rights.

regard to that party'. The European Court has also drawn a clear distinction, as regards the ratione temporis principle, as between killings and disappearances, the latter giving rise to a continuing procedural obligation to investigate that will persist as long as the victim's fate remains unaccounted for. See European Court, Varnava and Others $v$ Turkey, supra n 66, para 148.

${ }^{84}$ Also in the context of enforced disappearances, see African Commission, JE Zitha and PJL Zitha (represented by Prof Dr Liesbeth Zegveld) v Mozambique, supra n 70, para 93.

85 African Court, Beneficiaries of the Late Norbert Zongo and others v. Burkina Faso, No 13/2011, Judgment,28 March 2014.

86 Inter-American Court, Almonacid Arellano et al $v$ Chile, Preliminary exception, merits, reparations and costs, Judgment of 26 September 2006, Series C 154 (2006), paras 47 to 49 . The Court listed a series of examples of such violations which had arisen in previous cases: 'the decision of a judge not to allow the counsel for the defense to participate in the proceeding; the prohibition imposed on the counsels for the defense to interview their clients in private, to duly examine the record of the case, to forward evidence for the defense, to challenge incriminating evidence, and to prepare the arguments in due time; the intervention of 'faceless' judges and prosecutors; the torture or ill-treatment inflicted on the defendant to exact a confession from him; the failure to inform foreign detainees of their right to have consular assistance; and the violation of the principle of coherence or correlation between the charges and the judgment'.

87 European Court, Šilih v. Slovenia, Application No 71463/01, Judgment, 9 April 2009. See also European Court, Varnava and Others v Turkey, supra n 66, para 147.

88 The Human Rights Committee's assessment of the effectiveness of an investigation into a fatality is not limited to the right to life (Article 6 ICCPR), but also encompasses the right to an effective remedy (Article 
However, the European Court has been required to delve further into this issue, and has concluded that, in view of the principle of legal certainty, its temporal jurisdiction as regards the duty to investigate cannot be considered to be open-ended: there must therefore be a 'genuine connection' between the death and the entry into force of the Convention in respect of the respondent State for the procedural obligations imposed by the right to life (Article 2) to come into effect. This means that a 'significant proportion' of the procedural steps should usually have taken place after the entry into force of the Convention, although the Court accepted that 'in certain circumstances the connection could also be based on the need to ensure that the guarantees and the underlying values of the Convention are protected in a real and effective manner' (the 'Convention values test'). ${ }^{89}$ In the subsequent case of Janowiec and others $v$ Russia, concerning the execution in 1940 of more than 21,000 Polish prisoners of war by the

2 ICCPR) and also the prohibition of inhuman treatment (Article 7 ICCPR). However, under the Covenant the right to an effective remedy can only be breached in conjunction with another substantive right, so if a death occurs outside the Human Rights Committee's temporal jurisdiction, there cannot be a breach of the right to an effective remedy (Article 2) in conjunction with the right to life (Article 6). See: Human Rights Committee, S.E. v. Argentina (275/1988), Admissibility, CCPR/C/38/D/275/1988 (1990). In that case, the applicant's three children had been abducted by Argentine security forces in 1976, but the Covenant and Optional Protocol only entered into force in respect of Argentina in 1986. See also: Human Rights Committee, Maria Otilia Vargas v. Chile (represented by Fundación de Ayuda Social de las Inglesias Cristianas) (718/1996), Admissibility, CCPR/C/66/D/718/1996/Rev. 1 (1999); Human Rights Committee, Norma Yurich v. Chile (1078/2002), Admissibility, CCPR/C/85/D/1078/2002 (2005). In the case of Human Rights Committee, Mariam Sankara et al. v. Burkina Faso (1159/2003), Admissibility, CCPR/C/86/D/1159/2003 (2006), the Human Rights Committee found it had jurisdiction ratione temporis in relation to the investigation into the disappearance of Thomas Sankara, who had been abducted and murdered in 1987, prior to Burkina Faso becoming a party to the Optional Protocol in 1999. The Human Rights Committee declared admissible the complaints brought by Mr Sankara's widow and children arising from the failure to conduct an inquiry and prosecute the guilty parties, ultimately finding a violation of Article 7 (the prohibition of inhuman treatment), recognising the suffering experienced by his relatives (as well as a violation of Article 14 (the right to equality)). The European Court has found that the anguish and distress caused by the disappearance of a close relative may give rise to a violation of the prohibition of inhuman and degrading treatment (Article $3 \mathrm{ECHR}$ ), reflecting the reactions and attitudes of the authorities once a particular situation has been brought to their attention (see, e.g., European Court, Varnava and Others v Turkey, supra n 66, para 200).

See also Human Rights Committee, General Comment No 31, Nature of the General Legal Obligation Imposed on States Parties to the Covenant, CCPR/C/21/Rev.1/Add.13 (2004), para 15, which states, inter alia that 'a failure by a State Party to investigate allegations of violations could in and of itself give rise to a separate breach of the Covenant'.

89 European Court, Šilih v Slovenia, supra n 86, para 163. Note, however, the extent of dissension to these tests as expressed in the various concurring and dissenting opinions to the Šilih judgment. For a 'genuine connection' to be established, both criteria must be satisfied: the period of time between the death as the triggering event and the entry into force of the Convention must have been reasonably short, and a major part of the investigation must have been carried out, or ought to have been carried out, after the entry into force (European Court, Janowiec and others v Russia, Applications Nos 55508/07 and 29520/09, Judgment, 21 October 2013, para 148). 
Soviet Union (the Katyn massacre), the majority of the grand chamber further defined these conditions:

\begin{abstract}
'a required connection may be found to exist if the triggering event was of a larger dimension than an ordinary criminal offence and amounted to the negation of the very foundations of the Convention. This would be the case with serious crimes under international law, such as war crimes, genocide or crimes against humanity, in accordance with the definitions given to them in the relevant international instruments' ${ }^{90}$
\end{abstract}

Applying the Šlih criteria, the majority of the grand chamber in Janowiec found that it could not examine the complaints about the failure to carry out an effective investigation, because of the ratione temporis principle, noting that Russia had ratified the Convention 58 years after the Katyn massacre, which took place more than ten years before the Convention itself came into existence. However, four dissenting judges ${ }^{91}$ argued that as the killings of the Polish prisoners were war crimes, the Court should have distinguished the case and found a violation of the right to life. The dissenters objected to the majority's narrow interpretation as to which 'procedural acts' are covered by the investigative obligation - those limited to the particular interests of the injured party and excluding other broader types of inquiry, such as those seeking to establish a historical truth. What was more significant for the dissenters was the clear trend in international law towards the recognition of a right to truth in gross violation cases (relying, inter alia, on the case-law of the Human Rights Committee).$^{92}$ Furthermore, in the dissenters' view, the majority erred in finding that the Convention values test could not be applied to events pre-dating the adoption of the Convention, a principle which they argued to be inconsistent with international law. ${ }^{93}$ Accordingly, the dissenting judges concluded that in view of the gravity and magnitude of the war crimes in question, considered together with the actions of the Russian authorities after the entry into force of the Convention, the Court should have acknowledged its jurisdiction in the case.

\footnotetext{
90 European Court, Janowiec and others v Russia, ibid, para 150. However the 'Convention values' clause cannot be applied to events which occurred prior to the adoption of the Convention, on 4 November 1950: Janowiec, para 151. As with the Šilih case, the various concurring and dissenting opinions to the Janowiec judgment reflect considerable disagreement with the majority's application of the ratione temporis principle. 91 Judges Ziemele, de Gaetano, Laffranque and Keller.

92 Human Rights Committee, Mariam, Philippe, Auguste and Thomas Sankara v. Burkina-Faso (1159/2003), Views, CCPR/C/86/D/1159/2003 (2006), para 12.2; Human Rights Committee, Schedko and Bondarenko v. Belarus (886/1999), Views, CCPR/C/77/D/886/1999 (1999), para 10.2

${ }^{93}$ The dissenting judges in Janowiec also referred to the Convention values test as the humanitarian clause'.
} 


\section{B. Exhaustion of domestic remedies and related temporal rules on submission of applications}

There have been close parallels in the development of the exhaustion of domestic remedies criterion within the three regional mechanisms, all of which require an assessment of the availability, sufficiency and effectiveness of any domestic remedies on which a respondent Government seeks to rely. ${ }^{94}$ Only the American Convention includes (in Article 46(2)) detailed explicit exceptions to the exhaustion rule where: a) the domestic legislation does not provide due process of law for the protection of the right that has allegedly been violated; $b$ ) the applicant has been denied access to the remedies under domestic law or has been prevented from exhausting them; or $\mathrm{c}$ ) there has been unwarranted delay in rendering a final judgment. ${ }^{95}$

In all three systems, the requirement to exhaust domestic remedies may not be applicable when human rights violations have been committed as part of a systemic or generalised practice, or where, as in the case of the African Commission, there is evidence of serious or massive violations. In Velásquez Rodríguez the Inter-American Court found that the obligation to exhaust domestic remedies is discharged 'if there is proof of the existence of a practice or policy ordered or tolerated by the government', the effect of which is to prevent normal recourse to such remedies ${ }^{96}$ The Court concluded in the same case that as regards cases of disappearances in Honduras in the early 1980s, any remedies which theoretically may have been available were in fact ineffective as the imprisonments were clandestine, formal requirements made them inapplicable in practice, complaints were simply ignored by the authorities, or the authorities threatened and intimidated the lawyers and judges involved. Such evidence was provided by the Commission, which was able to show that habeas corpus and criminal complaints were ineffective ${ }^{97}$ In a similar vein, the European Court has found that applicants may be absolved from exhausting domestic remedies if there are 'special circumstances', for example, where 'the national authorities [remain] totally passive in the face of serious allegations of misconduct or

\footnotetext{
94 See, for example Inter-American Court, Garibaldi v Brazil, Preliminary objections, merits, reparations and costs, Judgment of 23 September 2009, Series C 203 (2009), para 46; African Commission, 275/03, Article $19 v$ State of Eritrea (2007), para 74; European Court, Demopoulos and Others v Turkey, Applications Nos 46113/99, 3843/02, 13751/02, 13466/03, 10200/04, 14163/04, 19993/04, 21819/04, Decision, 1 March 2010 , para 70 .

${ }^{95}$ Article 50 of the African Charter also excludes from the exhaustion requirement remedies that are 'unduly prolonged'.

96 Inter-American Court, Velásquez Rodríguez v. Honduras, Preliminary objections, Judgment of 26 June 1987, Series C 1 (1987), para 68.

97 Inter-American Court, Velásquez Rodríguez v Honduras, Merits, supra n 1, paras 80-81.
} 
infliction of harm by State agents, for example where they have failed to undertake investigations or offer assistance'. ${ }^{98}$

A link between the failure to investigate and the question of the assessment of the effectiveness of domestic remedies has also been made by the African Commission. In Article $19 v$ Eritrea, which concerned the incommunicado detention of journalists in the early 2000 s, the Commission found that:

'Holding the victims incommunicado for over three years demonstrates a prima facie violation of due process of the law and in particular, Article 7 of the African Charter. By not taking any action to remedy the situation more than twelve months after the African Commission had been seized of the communication goes to demonstrate that the State has equally failed to demonstrate that domestic remedies are available and effective'. ${ }^{99}$

The African Commission has also held that in the case of 'massive violations', ${ }^{100}$ their pervasiveness means that the requirement to exhaust domestic remedies will not be applied, 'especially where the state took no steps to prevent or stop them'. ${ }^{101}$ In the case of Anuak Justice Council v Ethiopia, which concerned an alleged massacre of more than 400 members of the Anuak people (an indigenous minority group living in the south-western region of Ethiopia), the African Commission found that the state's response had been acceptable, in that it had established a commission of inquiry and alleged perpetrators had been indicted. ${ }^{102}$

Within the European system, there has been a more restrictive application in recent years of the rules relating to the timing of submissions of applications to the European Court, in the particular context of disappearance cases. ${ }^{103}$ For some years, the European Court expected applicants in

${ }^{98}$ European Court, Cyprus v Turkey, supra n 71, para 116.

${ }^{99}$ African Commission, Article 19 v Eritrea, supra n 93, para 76.

100 See Article 58 of the African Charter.

101 African Commission, 299/05, Anuak Justice Council v Ethiopia (2006), para 60.

102 Ibid, para 61.

${ }^{103}$ Both the European and Inter-American systems require applications to be lodged within 6 months of the exhaustion of domestic remedies, whereas the African Charter stipulates that petitions should be submitted within a 'reasonable time' after exhausting local remedies (Article 56(6) of the African Charter; cf Article 35(1) of the European Convention and Article 46(1)(b) of the American Convention). Nevertheless, with reference to the other two regional systems, the African Commission has applied a six months time limit in some cases: see, e.g., African Commission, 308/05, Michael Majuru v Zimbabwe (2008), para 109. This practice of the African Commission's has been criticised by Frans Viljoen as representing a 'strikingly inappropriate reliance on international law, which is a-contextual and loses sight of the purpose of the openended formulation in the Charter' (F. Viljoen, International Human Rights Law in Africa, $2^{\text {nd }}$ ed. (Oxford, OUP, 2012), 320). 
cases concerning deaths or disappearances to keep track of the progress of domestic investigations and to lodge their applications 'with due expedition' once they become aware (or should become aware) of the lack of an effective investigation. ${ }^{104}$ Although it had been the European Court's practice not to apply the six months rule to cases of disappearance, on the basis that the time limit could not run in respect of continuing violations, in 2009 the grand chamber in Varnava and Others $v$ Turkey found that there was an obligation on the relatives of the disappeared to act with the necessary expedition in order to avoid, for example, loss of evidence or witnesses being untraceable. Applicants must therefore 'make proof of a certain amount of diligence and initiative and introduce their complaints without undue delay'. ${ }^{105}$

The European Court in Varnava took pains to acknowledge the uncertainty and confusion which frequently follows a disappearance case, and noted the consensus in international law that it should be possible to prosecute such serious cases many years later, ${ }^{106}$ but it nevertheless concluded that applications in disappearance cases could be rejected as being out of time where there has been an excessive or unexplained delay by the applicants, after they became aware (or should have become aware) of the ineffectiveness of the domestic investigation, and where there is no immediate, realistic prospect of an effective investigation being provided in the future. The Court went on to stipulate that applications in complex disappearance cases should therefore be brought within 'several years' of the incident; a delay of ten years would require particular justification. ${ }^{107}$

The approach of the Inter-American Commission has been different to that followed by the European Court in Varnava. A petition must be filed with the Commission within a reasonable period of time if the rule of exhaustion of domestic remedies does not apply. The Rules of Procedure of the Commission indicate that this must be determined by the Commission taking into account 'the date of the alleged violation and the circumstances of each case'. The Commission, in application of this rule, has been flexible in its treatment of disappearance cases. For example, in the case of Octavio Rubén González Acosta v. Paraguay, who disappeared in December 1975, the petition was brought before the Commission in June 1999 and the Commission considered that it had been presented within a reasonable period of time

\footnotetext{
${ }^{104}$ European Court, Varnava and Others v Turkey, supra n 66, para 158. $105 \mathrm{Ibid}$, para 161.

106 The Court cited the International Convention for the Protection of All Persons from Enforced Disappearance and the Rome Statute of the International Criminal Court.

107 On the ten year 'limit', see the dissenting opinion of Judge Sajó in European Court, Er and Others $v$ Turkey, supra $\mathrm{n} 56$.
} 
'taking into account the date of the alleged violations, the possible existence of a situation of continuing violation of human rights, and the status of the various domestic remedies in Paraguay.'108

\section{Burden of proof}

Since its very first judgment, Velásquez Rodríguez v Honduras, in 1988, the Inter-American Court has imposed an obligation on state authorities to produce information and evidence in circumstances where the applicants are simply unable to do so, noting that disappearances are 'characterized by an attempt to suppress all information about the kidnapping or the whereabouts and fate of the victim'. ${ }^{109}$ Thus the Court has emphasised that 'the State cannot rely on the defense that the complainant has failed to present evidence when it cannot be obtained without the State's cooperation'. ${ }^{110}$

Similarly, according to the jurisprudence of the European Court, the general position is that while the applicant bears the burden of proving the case beyond reasonable doubt, the burden will be shifted back to the government where the events in question fall largely within the 'exclusive knowledge' of the authorities, as is the case, for example, where a detainee dies whilst in state custody or in respect of any person who is found dead or injured, or who has disappeared, in an area which is under the state's exclusive control. ${ }^{111}$ In such cases the authorities will bear the burden of providing a 'satisfactory and convincing explanation'. ${ }^{112}$ The Court is also entitled to draw strong inferences from the non-disclosure of crucial documents. ${ }^{113}$

Although in many of the African Commission's decisions the evidential basis for its findings is arguably unclear, ${ }^{114}$ one can glean some general approaches. The applicant will need to submit a prima facie case to pass the admissibility requirements in Article 56 of the Charter. Although the applicant will have the burden of proving the allegations as part of the merits of the case, the response of the government and willingness to engage with the Commission will determine the extent of this burden. A 'blanket denial of responsibility' from the state will result in the

\footnotetext{
108 Inter-American Commission, Case 12.358, Octavio Rubén González Acosta v Paraguay, Report No 83/03 (2003).

109 Inter-American Court, Velásquez Rodríguez v. Honduras, Merits, supra n 1, para 131.

$110 \mathrm{lbid}$, para 135.

111 European Court, Varnava and Others v Turkey, supra n 66, para 184.

112 European Court, Salman v Turkey, Application No 21896/93, Judgment, 27 June 2000, para 100.

113 European Court, Magomed Musayev and Others v Russia, Application No 8979/02, Judgment, 23 October 2008, para 85.

114 Viljoen, International Human Rights Law in Africa, $2^{\text {nd }}$ ed. (Oxford, OUP, 2012), 322.
} 
Commission deciding the case on the basis of the facts presented by the applicant. ${ }^{115}$ Although the African Commission has not always been consistent on this question, it has held that once the state contradicts the applicant, the burden of proof will shift to it.. ${ }^{116}$

\section{Relationship between the duty to investigate and the right to know the truth}

While the three regional systems recognise that there is a right to know the truth under international law, its treatment differs in part because of the varying socio-political contexts which shape the way they understand the right. The right to know the truth has been a pivotal element in the various transitional justice processes that have taken place in the Americas and Africa as illustrated by the cases of Argentina, Chile, Guatemala, South Africa and Kenya, although in many cases such mechanisms have arguably been used to avoid dealing with criminal investigations (i.e. 'truth instead of justice'). In European states, in contrast, with the exception of the various measures taken following World War II, the right to know the truth has not been given the same degree of attention, even though victims continue to claim it. An illustration of this is the case of Spain where years after Franco's dictatorship, state authorities continue to deny the fulfilment of this right. Indeed, in a recent visit to that country by Pablo de Greiff, the Special Rapporteur on Truth, Justice, Reparation and Guarantees of Non-recurrence, concluded that in Spain "[t]he most serious shortcomings are to be found in the spheres of truth and justice. No State policy was ever established with respect to truth; there is no official information and no mechanisms for elucidating the truth". ${ }^{117}$ A similar situation can be said to be taking place in Russia as illustrated by the Janowiec and others case $v$. Russia, which is discussed below.

The Inter-American and European Courts both recognise that victims, their next of kin and society as a whole have the right to know the truth about what happened. However, the two systems differ in their understanding of the relationship of the duty to investigate and the right to know the truth. For the Inter-American Court, the right to know the truth 'is subsumed in the right

\footnotetext{
115 African Commission, 74/92, Commission Nationale des Droits de l'Homme v Chad, 11 October 1995, paras 19 and 24. This was reaffirmed in African Commission, 27/89, 46/91, 49/91 and 99/93, Organisation Mondiale Contre la Torture and Association Internationale des Juristes Democrates, Commission Internationale des Juristes (CIJ), Union Interafricaine des Droits de l'Homme v. Rwanda (1996), para 20. See also African Commission, 143/95 and 150/96, Constitutional Rights Project and Civil Liberties Organisation v. Nigeria (1999), para 28.

${ }^{116}$ African Commission, 71/92, Rencontre Africaine pour la Défense des droits de l'homme (RADDHO) $v$ Zambia (1997), para 27.

117 Report of the Special Rapporteur on Truth, Justice, Reparation and Guarantees of non-repetition: Mission to Spain, A/HRC/27/56/Add.1, 22 July 2014, p. 1.
} 
of the victim or his next of kin to obtain clarification of the facts relating to the violations and the corresponding responsibilities from the competent State organs, through the investigation and prosecution established in Articles 8 and 25 of the Convention. ${ }^{118}$ While more recently the InterAmerican Court has been ready to concede that the right to know the truth can also involve other rights under the Convention such as the right of access to information under Article 13, there is an intimate relationship between the right to know the truth and the duty to investigate. Consequently, the Court has held that the establishment of a truth commission, as valuable as it may be, is not sufficient to fulfil the obligation to investigate or the victim's right to know the truth. The State will still have an obligation to 'open and expedite criminal investigations to determine the corresponding responsibilities. ${ }^{119}$

In contrast, the European Court has maintained that the duty to investigate and the right to know the truth are different. In the Janowiec $v$. Russia case, relating to the Katyn massacre (see section 4A above), the Court said that it 'considers that the reference to 'procedural acts' must be understood in the sense inherent in the procedural obligation under Article 2 or, as the case may be, Article 3 of the Convention, namely acts undertaken in the framework of criminal, civil, administrative or disciplinary proceedings which are capable of leading to the identification and punishment of those responsible or to an award of compensation to the injured party [...]. This definition operates to the exclusion of other types of inquiries that may be carried out for other purposes, such as establishing a historical truth.' ${ }^{120}$

The consequences of this approach are not without importance. For example, if the European Court decides that it has jurisdiction ratione temporis (see section $4 \mathrm{~A}$ above) over the obligation to investigate, this would not necessarily include the right to know the truth, at least not in relation to establishing the truth outside legal proceedings. The Inter-American Court, however, would look at the wider dimensions of the right to know the truth when considering the obligation to investigate.

\footnotetext{
118 Inter-American Court, Bámaca-Velásquez v Guatemala, Merits, Judgment of 25 November 2000, Series C 70 (2000), para 201.

119 Inter-American Court, Massacre of el Mozote v El Salvador, Merits, reparations and costs, Judgment of 25 October 2012, Series C 252 (2012), para 298; see also Report of the Inter-American Commission on Human Rights, Report on the Right to Truth in the Americas, OEA/Ser.L/V/II.152.Doc.2, 13 August 2014, p. 36-57.

${ }^{120}$ European Court, Janowiec and others v. Russia, supra n 88, para 143.
} 
There are signs, however, that the European Court may be willing to broaden its outlook. In the El-Masri case, concerning the phenomenon of 'extraordinary rendition', the Court explicitly recognised the negative impact that an inadequate investigation can have on the right to know the truth (not only of other victims of rendition, but also of the general public) and stated that an adequate investigation should lead both to the identification of the perpetrators and to establishing the truth of what happened. ${ }^{121}$

Despite the establishment of truth and reconciliation bodies in a number of African states (South Africa, Liberia and Kenya, for example), and although the African Commission has recognised the right to know the truth, it has not defined its scope or reach in its communications. What it has done, however, is to require that there must be a sufficient element of public scrutiny not only of the investigation but also of its results ${ }^{122}$ to secure accountability in practice as well as in theory. ${ }^{123}$ The degree of public scrutiny required may well vary from case to case.

\section{Reparations}

The Inter-American Court and the African Commission share an expansive approach to the question of reparations. As regards cases of disappearances and extra-judicial executions, the Inter-American Court has frequently ordered the state to carry out investigations, it has upheld the right of relatives (and of wider society) to be informed about what happened, ${ }^{124}$ and has ordered states to locate the remains of victims and provide them to the next-of-kin. ${ }^{125}$ It has justified its position by explicitly finding that the nature and gravity of cases of gross violations of human rights may require more than a declaratory response. ${ }^{126}$

121 European Court, El-Masri v. Macedonia, No 39630/09, Judgment,13 December 2012, para 191 and 193. See also European Court, Al Nashiri V. Poland, No 28761/11, Judgment, 24 July 2014; European Court, Husayn (Abu Zubaydah) v Poland, No 7511/13, Judgment, 24 July 2014.

122 African Commission, Amnesty International, Comité Loosli Bachelard and Lawyers Committee for Human Rights, Association of Members of the Episcopal Conference of East Africa v Sudan, supra $\mathrm{n} 15$.

123 African Commission, Sudan Human Rights Organisation and Centre on Housing Rights and Evictions (COHRE) $v$ The Sudan, supra n 9, para 150.

124 Inter-American Court, Myrna Mack Chang v Guatemala, Merits, reparations and costs, Judgment of 25 November 2003, Series C 101 (2003), para 274.

125 Inter-American Court, Bámaca Velasquez v Guatemala, Reparations and costs, Judgment of 22 February 2002, Series C 91 (2002), para 79.

126 Inter-American Court, El Amparo v Venezuela, Reparations and costs, Judgment of 14 September 1996, Series C 28 (1996), para 35. 
It is important to note that the Inter-American Court does not distinguish between violations when awarding reparation; in other words, it will not indicate that the reparations awarded correspond to the violation of specific rights. However, a careful analysis of the grounds and evidence on which the Court makes such awards can establish a link between a particular reparations order and the duty to investigate. For example, a frequently awarded form of reparation by the Inter-American Court in right to life cases is the requirement for the publication of the judgment. ${ }^{127}$ This can be considered to provide redress for a lack of due diligence in investigations, given that it enables others to know what were the particular failings in the investigation. The Court has also ordered that prosecutors, judges and members of the military or security forces, or other state institutions, be provided with training in particular areas of international human rights law and humanitarian law. ${ }^{128}$ The Inter-American Court has also recognised that the grounds for claiming moral damages include the denial of justice and the persistence of impunity and has accordingly awarded compensation on equitable grounds on that basis. ${ }^{129}$

Similarly, the practice of the African Commission is to call on states to carry out investigations in cases of killings or disappearances. ${ }^{130}$ For example, Malawi African Association and Others $v$. Mauritania ${ }^{131}$ concerned the treatment of Black Mauritanians in the period between 1986 and 1992, including the detention of hundreds of people, the fate of many of whom remained unknown. The Commission found a series of grave or massive violations of the rights in the Charter and accordingly required the respondent state to establish an independent enquiry 'in order to clarify the fate of persons considered as disappeared, identify and bring to book the authors of the violations perpetrated at the time of the facts arraigned'.

$127 \mathrm{lbid}$, paras 273-275 (as an example).

${ }^{128}$ Inter-American Court, Myrna Mack Chang v. Guatemala, supra n 122, para 282; Inter-American Court, Case of the 'Las Dos Erres Massacre' $v$ Guatemala, Preliminary objection, merits, reparations and costs, Judgment of 24 November 2009, Series C 211 (2009), operative para 12.

129 Inter-American Court, Myrna Mack Chang v Guatemala, Ibid, para 264; Inter-American Court, García Lucero et al $v$ Chile, supra n 60, para 246. The European Court has acknowledged that the gravity of a case will affect the level of a non-pecuniary damages award, as will the period of time during which an issue has remained unresolved. However, claims for punitive damages have been consistently rejected by the European Court. See: European Court, Varnava and Others v Turkey, supra n 66, paras 223-225.

${ }^{130}$ As to the legal status of the Commission's decisions, see Viljoen, International Human Rights Law in Africa, 339: 'State parties have not only accepted the Charter as binding, they have also accepted the competence of the African Commission to interpret the Charter and to decide individual communications'.

131 African Commission, 54/91, 61/91, 98/93, 164/97 à 196/97 and 210/98, Malawi Africa Association, Amnesty International, Ms Sarr Diop, Union interafricaine des droits de l'Homme and RADDHO, Collectif des veuves et ayants-Droit, Association mauritanienne des droits de l'Homme v Mauritania (2000). 
The case of Zimbabwe Human Rights NGO Forum v Zimbabwe concerned the political violence which erupted following the constitutional referendum in February 2000, prior to parliamentary elections held later that year. The Commission found that the majority of human rights violations were committed by non-state actors, however, the victims' rights to judicial protection and to have their cause heard (Article 7 of the Charter) had been violated because of the passing of a clemency order which had the effect of prohibiting prosecutions and setting free the perpetrators of 'politically-motivated crimes'. As a result, the Commission called on the Republic of Zimbabwe to establish a Commission of Inquiry 'to investigate the causes of the violence.... and bring those responsible for the violence to justice, and identify victims of the violence in order to provide them with just and adequate compensation'. ${ }^{32}$

In making an order for reparations in terms of an investigation, the Inter-American Court goes further than simply enunciating the bare obligation; it fleshes out what it will entail in the specific case, in considerable detail, in order for the investigation to be effective. For example, in the case of Manuel Cepeda Vargas v Colombia, which concerned the extra-judicial execution in 1994 of a Senator, who was killed as part of a plan to exterminate his political party, the Patriotic Union, the Court found that various violations of the duty to investigate with due diligence had taken place and therefore required the State: to 'investigate effectively all the facts and background of this case, including... all the necessary measures to detect and reveal patterns of systematic violence against the collectivity to which Mr. Cepeda belonged'; to identify all those involved; to 'establish coordination mechanisms between the different State organs and institutions with powers to investigate, and other existing or future entities in order to conduct the most coherent and effective investigation'; to remove all obstacles to justice; to investigate all links between state authorities and members of paramilitary groups; to ensure that members of paramilitary groups who had been extradited to the US would be accessible to secure justice in Colombia; to ensure that those involved in the investigations as well as victims and witnesses had at their disposal the necessary protection mechanisms; and to ensure that the results be publicised. ${ }^{133}$

\footnotetext{
132 African Commission, 245/02, Zimbabwe Human Rights NGO Forum v Zimbabwe. See also African Commission, 292/2004, Institute for Human Rights and Development in Africa v Republic of Angola, (2008) in which the Commission recommended, inter alia, that the Republic of Angola should: "establish a Commission of inquiry to investigate the circumstances under which the victims were expelled and ensure the payment of adequate compensation of all those whose rights were violated in the process.' A further example is African Commission, 204/97, Mouvement burkinabé des droits de l'Homme et des peuples $v$ Burkina Faso (2001).

133 Inter-American Court, Manuel Cepeda Vargas v Colombia, supra n 8, paras 214-218.
} 
In disappearance cases or those involving massacres where victims are yet be found and identified, the Inter-American Court has also ordered that the effective search of the whereabouts of the victims should continue, stipulating detailed conditions. ${ }^{134}$

In the Cotton Field case, concerning gender-based violence in Ciudad Juárez in Mexico, the Court not only required the respondent state to ensure the effective prosecution of such cases (in respect of both the perpetrators and masterminds) but also stipulated that the investigation must include a gender perspective and include specific lines of inquiry concerning sexual violence. ${ }^{135}$ The Court may also stipulate that investigators should take account of systematic patterns of human rights violations. ${ }^{136}$

The position of the European Court of Human Rights in relation to redress for failing to carry out effective investigations into cases of fatalities remains considerably undeveloped, in comparison to the stance of both the Inter-American Court and African Commission. ${ }^{137}$ The European Court has developed its right to life jurisprudence notably in response to a series of cases from Northern Ireland, and in cases arising out of the conflicts in Turkey since the 1990s and in Chechnya in the 2000s. There have been multiple instances in both Turkey and Russia of cases of disappearances and extra-judicial killings, on which the European Court has been called to adjudicate. It may be that the European Court's relatively limited and conservative approach to redress in such cases can be explained in part by the different contexts on which the InterAmerican and African Commission have had to rule. The European Court's practice has been to reject applicants' requests that states be ordered to carry out investigations, with the Court preferring to leave the respondent state to choose how to comply with its judgments, subject to supervision by the Committee of Ministers. ${ }^{138}$

However, a number of European judges have, in more recent years, questioned whether the Court should not go further, especially in cases of enforced disappearance. For example, in

\footnotetext{
134 Ibid, para 268.

135 Inter-American Court, Cotton Field v Mexico, supra n 61, operative para 12.

136 Inter-American Court, Ibsen Cárdenas and Ibsen Peña v Bolivia, Merits, reparations and costs, Judgment of 1 September 2010, Series C 217, para 237.

137 See further: Leach, 'No longer offering fine mantras to a parched child? The European Court's developing approach to remedies', in Constituting Europe - The European Court of Human Rights in a National, European and Global Context, eds. Føllesdal, Schlütter \& Ulfstein (Cambridge University Press, 2013), 171-177.

138 See, for example, European Court, Varnava and Others v Turkey, supra n 66, para 222.
} 
Medova $v$ Russia in 2009, which concerned the disappearance of Adam Medov in Ingushetia in 2004, Judge Spielmann, in his partly dissenting opinion, argued that in view of the multiple shortcomings in the investigation which the Court had identified, it should also have ordered the state to carry out effective investigation:

'...many of these shortcomings...might still be redressed in the particular circumstances of this case if an investigation were conducted even after so many years' ${ }^{139}$

Similar sentiments were expressed by Judges Spielmann, Ziemele and Kalaydjieva in their concurring opinion in Varnava and others $v$. Turkey, relating to the disappearance of the applicants' relatives following their detention by Turkish armed forces in northern Cyprus in 1974. ${ }^{140}$ There are clear signs too, that the nature and scale of the human rights violations committed in Chechnya (and other republics in the north Caucasus region of Russia) have led to further developments in the European Court's thinking on redress. The case of Abuyeva and others $v$. Russia,${ }^{141}$ concerned deaths of civilians caused by the shelling of a village in Chechnya in 2000 by the Russian armed forces. The Abuyeva judgment was published in 2010, five years after the judgment in the case of Isayeva $v$ Russia ${ }^{142}$ relating to the very same incident, but in spite of the passage of time, an effective investigation had still not been carried out into the attack. The European Court came to the view that an effective investigation into the case was still possible, therefore, whilst acknowledging that Russia's compliance with the judgment would be assessed by the Committee of Ministers, the Court considered it 'inevitable that a new, independent, investigation should take place'. ${ }^{143}$ The Abuyeva decision was followed in 2012 by its judgment in Aslakhanova $v$ Russia in which the European Court found, for the first time, that ineffective criminal investigations into the circumstances of disappearances in the North Caucasus, notably between 1999 and 2006, were widespread and systemic. ${ }^{144}$ The Court again found that it could not order the performance of particular measures of redress, but it considered itself to be 'compelled' to provide 'guidance' on steps that were required by the respondent state:

\footnotetext{
139 European Court, Medova v. Russia, Application No 25385/04, Judgment, 15 January 2009. See also his similar dissenting opinion in European Court, Umayeva v. Russia, Application No 1200/03, Judgment, 4 December 2008.

140 European Court, Varnava and others v. Turkey, supra n 66.

141 European Court, Abuyeva and others v. Russia, Application No 27065/05, Judgment, 2 December 2010.

142 European Court, Isayeva v. Russia, Application No 57950/00, Judgment, 24 February 2005.

143 European Court, Abuyeva and others v. Russia, supra n 139, para 243.

144 European Court, Aslakhanova v Russia, supra n 34.
} 
'Such steps should be taken with the aim of putting an end to the continued suffering of the relatives of the disappeared persons, conducting effective investigations into the cases of abduction, unlawful detention and disappearance allegedly committed by servicemen, and ensuring that the families of the victims are awarded adequate redress'. ${ }^{145}$

The particular measures stipulated by the Court in Aslakhanova were the following: create a single, sufficiently high-level body in charge of solving disappearances in the region; compile and maintain a unified database of all disappearances; the allocation of specific and adequate resources required to carry out large-scale forensic and scientific work on the ground, including the location and exhumation of presumed burial sites; the collection, storage and identification of remains and, where necessary, systematic matching through up-to-date genetic databanks; the payment of financial compensation to the victims' families; the possibility of unilateral remedial offers to the relatives, including an undertaking to conduct, under supervision of the Committee of Ministers, an ECHR-compliant investigation; and the continuing obligation to investigate the situations of known or presumed deaths of individuals. ${ }^{146}$ As regards the ongoing obligation to carry out effective investigations, the Court also underlined the need for the investigating authorities to identify the leading agencies and commanding officers who were involved in the special operations in question, and clarify who was responsible for any detainees, and for the investigators to have unhindered access to data held by the security forces. ${ }^{147}$

A further development on point was taken by the European Court in its judgment relating to the crackdown on anti-government demonstrations in Bucharest in December 1989, around the time that Nicolae Ceauşescu was overthrown (Association '21 December 1989' and Others v. Romania $\left.{ }^{148}\right)$. Having found that there had been widespread use of lethal force against the demonstrators, and that the subsequent investigation had been ineffective, because of the statutory limitation of criminal liability, the Court stipulated that the victims should therefore be

\footnotetext{
$145 \mathrm{Ibid}$, para 221. The measures set out by the Court were not included in the operative provisions of the judgment, and accordingly, were not strictly legally binding on the respondent state.

146 Ibid, paras 222-238.

147 Ibid, paras 233-234.

148 European Court, Association '21 December 1989' and Others v. Romania, Application No 33810/07, Judgment, 24 May 2011.
} 
provided with an effective investigation 'in view also of the importance to Romanian society of knowing the truth about the events'. ${ }^{149}$

\section{Conclusions}

Overall there is a striking similarity in the broad approach of the three regional systems in their interpretation and application of the duty to investigate in respect of right to life cases. Although the systems have employed differing wording to describe the essential nature of the duty to investigate (requiring either 'due diligence' or an 'effective official investigation'), each identifies six core elements: investigate on the state's own initiative; conduct an effective investigation; ensure promptness and reasonable expedition; maintain independence and impartiality; allow public scrutiny; and ensure the involvement of the next-of-kin. There are some differences in wording which do not, however, actually indicate a divergent approach (such as the InterAmerican and African requirement for a 'serious' investigation).

Where some distinctions are apparent, these may in fact be more the result of lack of clarity on certain points (such as the burden of proof, the triggering moment, and the question whether the duty amounts to an obligation of result or one of means) rather than an actual difference in approach. Indeed, we would suggest that this chapter highlights a number of areas where there is a need for greater clarity from one or more of the regional systems. For example, whereas the European and Inter-American Courts have stipulated that the duty extends to the prosecution and punishment of the perpetrators, that has yet to be clarified by the African institutions.

Other areas of divergence arguably stem from a comparatively larger number of cases in one of the regional systems which raise a particular serious issue (for example disappearances), which coupled with rampant impunity and the repetitive failure of the State in question to implement the orders of the Inter-American Court, create serious reasons for concern, and which have therefore required the system in question to place greater focus on the point and to find ways to pressure the respective State to address the situation it faces. We have in mind here the way in which the Inter-American bodies have imposed on states stricter investigatory obligations as regards systemic cases, than either the African or European systems have yet had cause to do.

Following on from this, the varied socio-political contexts of the three regional systems undoubtedly account for certain differences in the case-law. While all three mechanisms

149 Ibid, para 130. 
recognise the right to know the truth, the states in the Americas turned this right into a pivotal element of their transitional justice processes as at the very least, repressive dictatorships in the region were ready to allow some truth instead of criminal accountability processes. The way criminal investigations were a trade-off in the region, forced the Inter-American System to take a stand on the issue and to establish that while the right to know the truth is a clear entitlement under the American Convention, it is intrinsically related to the obligation to investigate (as well as to other rights) so, truth without justice is not allowed under the American Convention. This stands in contrast with the European jurisprudence that appears to allow truth without justice if certain conditions are met.

Where there are significant differences in approach, such as for the award of reparations, this may be attributed to a variety of factors, including the drafting histories of the respective treaties. For example, some commentators on the Inter-American system have alluded to the intention of those who were involved in drafting the American Convention to ensure that the Inter-American Court had broad powers to order reparations, ${ }^{150}$ whereas that was not the case as regards the European Court. ${ }^{151}$ The greater gravity and scale of cases before the Inter-American and African systems may be another reason why those systems have been prepared to take the issue of reparations a good deal further than the European Court. It can also be explained if the human rights regional courts see their role as one of exercising corrective justice, whereby they not only address the violations and the harm caused by human rights abuses, but they also try to trigger structural changes for vulnerable communities that have been affected by them.

As we have discussed, the European Court's approach to redress has been developed in recent years, albeit more often through its use of recommendations. The Inter-American Court's redress provisions are included within its operative provisions, and are therefore unquestionably legally binding, but that was not the case as regards the European Court's recent stipulations in Abuyeva, Aslakhanova or Association '21 December 1989', which therefore can only be (strictly) considered as 'recommendations'. Divergent attitudes towards redress are also a consequence of differences in the roles that the respective treaty bodies are expected to play with respect to reparations and in follow up on decisions. Whereas the Inter-American bodies, and to a certain extent the African Commission, are more willing to specify the actions the state must take in

150 Pasqualucci, The Practice and Procedure of the Inter-American Court of Human Rights, $2^{\text {nd }}$ ed. (Cambridge University Press, 2013), 190.

${ }^{151}$ Shelton, Remedies in International Human Rights Law, $2^{\text {nd }}$ ed. (Oxford University Press, Oxford, 2005), 189-192. 
order to comply with its decision, in the European system it is the Committee of Ministers, not the European Court, which has the task of supervising the execution of judgments. ${ }^{152}$ This does not mean that the Court, as amplified by Judges Spielmann, Ziemele and Kalaydjieva in their concurring opinion in Varnava 'should not play any part in the matter and should not take measures designed to facilitate the Committee of Ministers' task in discharging these functions', ${ }^{153}$ but it does explain the lack of detail in its judgments when compared with the InterAmerican and African bodies. Indeed, we would argue that if the European Court is now empowered to include in its operative provisions, for example, a requirement that an applicant who was unlawfully dismissed be reinstated, ${ }^{154}$ then it would also seem to be possible for it to order a respondent state, in a case concerning an unresolved killing or disappearance, to carry out an effective investigation.

We have detected a considerable degree of borrowing of concepts and jurisprudence from and between each of the regional bodies, particularly around general concepts. This is not always consistently applied and it is not always clear why the jurisprudence and practice of the other bodies are not acknowledged. For example, there have been significant developments in the European Court's approach to redress in gross violation cases in recent years, which have been made without express reliance on the case-law of the Inter-American Court, which is a surprising and regrettable omission. ${ }^{155}$ Clara Sandoval has previously highlighted the InterAmerican Court's creative use of Article 29 of the American Convention in order to enhance human rights protection: ${ }^{156}$ Article 29 obliges the Court to take account, inter alia, of other international treaties when interpreting the Convention. For example, the Inter-American Court has applied Article 29 in conjunction with Article 8(1) (the right to a fair trial) in finding that the next-of-kin of the disappeared have the right to have an effective investigation, taking due account of the UN Declaration on the Protection of All Persons Against Enforced

\footnotetext{
152 Pursuant to Article 46(2) of the European Convention on Human Rights. 153 European Court, Varnava and others v. Turkey, supra n 66.

154 European Court, Oleksandr Volkov v Ukraine, Application No 21722/11, Judgment, 9 January 2013. 155 It is noticeable that a research report published by the Court in 2012 on 'References to the InterAmerican Court of Human Rights in the case-law of the European Court of Human Rights' (Council of Europe/European Court of Human Rights, 2012), includes cases in which reliance has been placed on the Inter-American Court's jurisprudence as to both the substantive law and various procedural issues (such as questions of admissibility and interim measures), but not as regards questions of redress.

156 Sandoval, 'The Inter-American System of Human Rights and Approach', in Sheeran and Rodley (eds.), The Routledge Handbook of International Human Rights Law, (Routledge, London and New York 2013), 427-443, 437. A comparable provision in the European Convention on Human Rights - Article 53 - has not been invoked by the European Court in considering reparations or redress.
} 
Disappearance. ${ }^{157}$ Similarly, Articles 60 and 61 of the African Charter provide the African Commission with the mandate to refer to other treaties and jurisprudence of the European and Inter-American bodies, among others. Indeed, as has been shown above, it is evident from the practice of the African Commission that it is strongly influenced by the jurisprudence from the other regional bodies, often citing extensively from their case law and on some occasions adopting it as its own. The movement of borrowing and sharing concepts, however, appears to be greater in some directions (from the Inter-American and European to the African) than others (from the African to the Inter-American and European).

${ }^{157}$ Inter-American Court, Blake v Guatemala, Merits, Judgment of 4 January 1998, Series C 36, paras 9697. 